Wacana Vol. 17 No. 1 (2016): 38-67

\title{
An account of the loss of the Country Ship Forbes and Frazer Sinclair, her late Commander
}

\author{
HORST H. LIEBNER AND DAVID VAN DYKE
}

\begin{abstract}
This paper reports on the life of the English Country trader Captain Frazer Sinclair leading up to and following the loss of the Forbes in the Karimata Strait in 1806. It examines the adventure and tenuous times of trading around the Indonesian archipelago after the fall of the VOC and subsequent transfer to the British. Included are the details of Captain Sinclair's trading history, multiple prizes as a privateer, and shipwrecks.

KEYWORDS

English Country trade; Captain Frazer Sinclair; opium; privateer; Forbes; Karimata Strait; Letter of Marque.
\end{abstract}

Running before a favourable easterly wind well into the third hour of 11 September 1806, the British country ship ${ }^{1}$ Forbes, out of Calcutta under Captain Frazer Sinclair, most unexpectedly "struck and stuck on a reef of rocks at the South entrance of the Straits of Billiton" (Figure 1). ${ }^{2}$

1 A ship which was employed in the local trade in Asia and the Far East was known as a Country Ship. These ships were owned by local shipowners in the east, many of which had long standing connections with the Company. As well as collecting cargo from outlying places to particular ports, ready for loading on the Regular ships for transhipment to England, the Country ships traded freely all year round [http://www.eicships.info/help/shiprole.html].

2 This and the following unmarked details on the Forbes' last voyage are compiled from two reports of the wreckage, found in the Prince of Wales Island Government Gazette (in the following, PWIG) 11-10-1806, shown in Figure 1, and in a supplement to the Bombay Courier 03-01-1807, here not presented. For supplying scans of all surviving editions of the PWIG until

HORST H. LIEBNER was a researcher into maritime culture and the history of the Malay Archipelago. He is an expert Staff at Centre for Research on Sea Territories and Non-Living Resources, Agency for Marine and Fisheries Research, Department of Marine Affairs and Fisheries of Indonesia. His publications include The Siren of Cirebon; A Tenth-Century Trading Vessel Lost in the Java Sea (2014). Horst Liebner may be contacted at: khmail@indosat.net.id.

DAVID VAN DYKE is a divemaster who has worked on underwater projects in Aceh, Belitung, Borneo, and the Java Sea. David's research interests include the Karimata Strait, Gaspar Strait, and Java Sea shipwrecks. He can be reached at: dv4631@yahoo.com.

(C) 2016 Faculty of Humanities, University of Indonesia

HORST H. LIEBNER AND DAVID VAN DYKE | DOI: 10.17510/wacana.v17i1.449 
Her crew, so spitefully thrown out of their routine and sleep, presently lowered the ship's tenders, and tried their utmost to get the vessel off the cliff; yet, the hull apparently being breached, "about two hours after, the stern went down in 5 fathoms", and, as witnessed by the wreck's present site, the Forbes slipped off the reef into the 30-odd meter she now rests. With dawn breaking, the ship's company of 78 European officers and tars, Indian seacunnies and Laskar sailors now found themselves, some 600 nautical miles from the nearest English settlement, in but their boats - and that, as will become apparent presently, in a sea claimed by Britain's current enemies, the Batavian Republic and her confederate, Napoleonic France, thus frustrating a landfall on nearer shores. Not only having lost the "property and treasure" the crew had gathered during the six preceding months, they now faced the hardships and dangers of a lengthy voyage in open boats through hostile quarters, an ordeal that could easily imperil their freedom, if not their lives.

The Forbes was almost brand-new: It was only a short 20 months since she, on 18 January of the previous year, and just as we had expected by the accounts of other launchings, had "glided into her destined element, amidst the admiration and applauses of a numerous assemblage of spectators". ${ }^{3}$ Built by a certain Matthew Smith at his yards at Howrah on the River Hooghly's banks opposite to Calcutta, this "very handsome vessel of 300 tons burthen" was registered as what then used to be called a "ship", "full-rigged" - meaning, carrying square sails on all of her three masts (Figure 2). To the day two months later, she made her maiden voyage to Bombay, then the most important British settlement on India's west coast, under the mutual protection against the French privateers known to haunt the Bay of Bengal in convoy with a dozen other ships, where she dropped anchor on 25 May of that year. We don't know when the Forbes returned to Bengal; yet, by 30 November the ship was back in Bombay, having

left the [Calcutta] Pilot on the 19th of September, and experienced light North East winds in her passage down the Bay of Bengal; off Ceylon they met with hard gales from West to S. W. Spoke H. M. ship Victor, in Lat. $17^{\circ} 15^{\prime} \mathrm{N}$. - On their passage up the coast they touched at Cannanore. Passengers, Colonel Forbes, to Point de Galle, L. Mackintosh, Esq. from Mangalore, and Mr. M'Leod who died at Sea (Bombay Courier 07-12-1806).

1816 we are indebted to Geoff Wade, then of the National University of Singapore.

3 Asiatic Annual Register [...] for the year 1808 (in the following, AAR NNNN) (1811: 96) describing the launch of Emma, for which see the following note. 


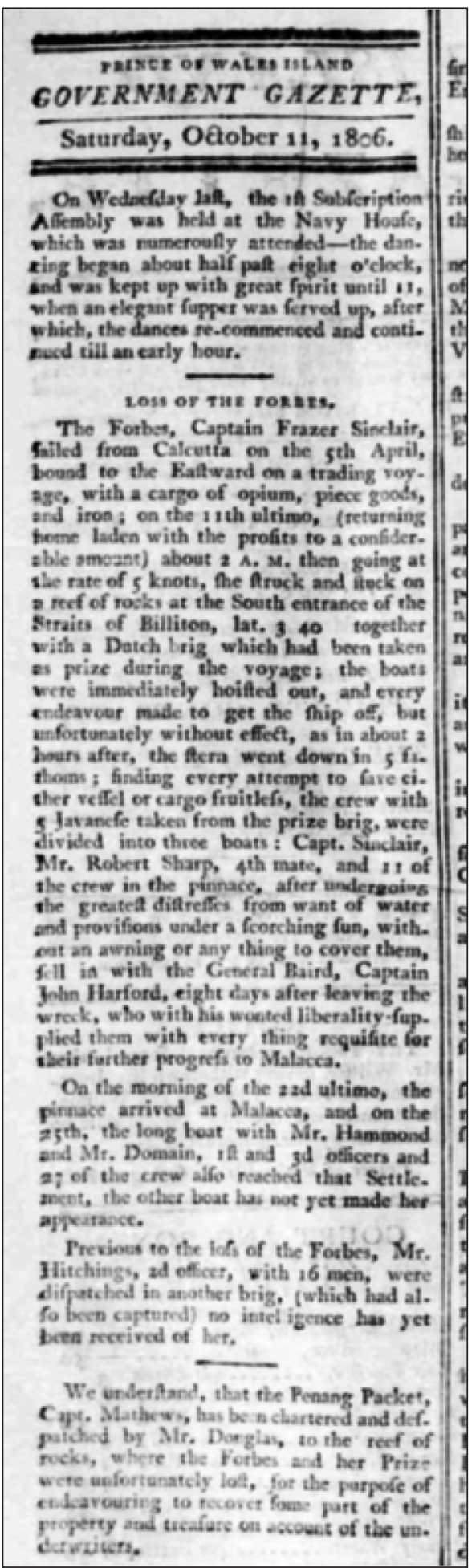

Figure 1. "Loss of the Forbes" (Prince of Wales Island Gazette 11-10-1806). 


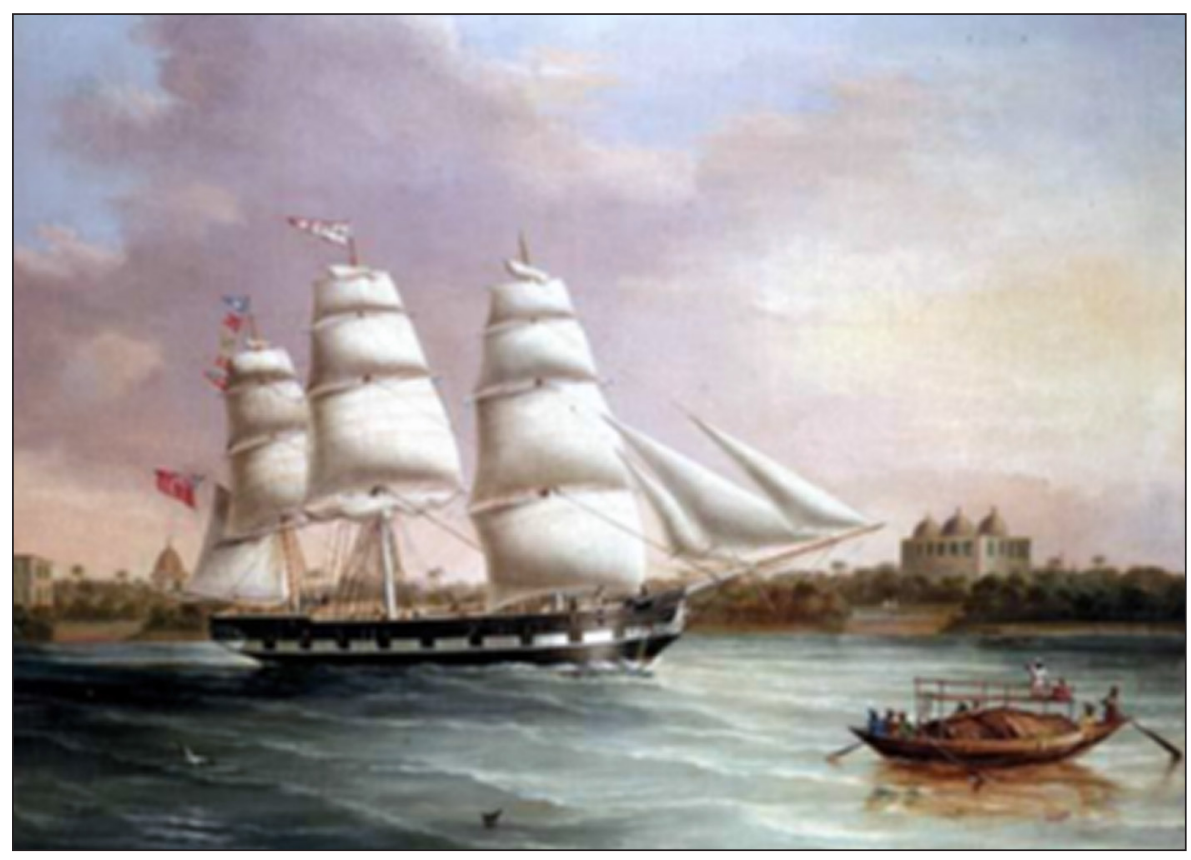

Figure 2. A British country trader, a "full-rigged ship", off Bombay, circa 1850 [http:/ / www.britannica.com/technology / ship/History-of-ships].

Colonel Forbes must have thought the ship's name a rather gratifying concurrence - and one wonders if the Bombay trading house of Forbes and Company (Figure 3), established in 1767 by the Scottish peer John Forbes and destined to become "one of the oldest businesses in the world" 4 that still today runs a number of successful enterprises in India, would not have found a vessel bearing their company's tag a carrier suitably appointed for their far-stretched commerce. However, in the ships' registers we could address, we noticed but two mentions of the Forbes: Her only appearance in the annual "List of Vessels belonging to the Port of Calcutta" in the first edition of the East India Register and Directory for 1806 omits the usual entry for a "managing owner" and, speciously by a printing mistake, notes the name of her captain in the line directly above as commander of a Fairlie; registered under "General No. 95" in Phipps 1840's Collection of Papers Relative to Ship Building in India, the vessel is correctly stated to have been "lost in the Java seas, 11th Sept. 1806", but neither her skipper nor proprietors are revealed (Figure 4).

4 For example, British Library Blog, “Untold Lives", 18-11-2013 (http:/ / britishlibrary. typepad.co.uk/untoldlives/2013 /01/forbes-and-company-one-of-the-oldest-businesses-inthe-world.html; compare for example, http://www.forbes. co.in/history_flash.htm, both last accessed 24-08-2015). 


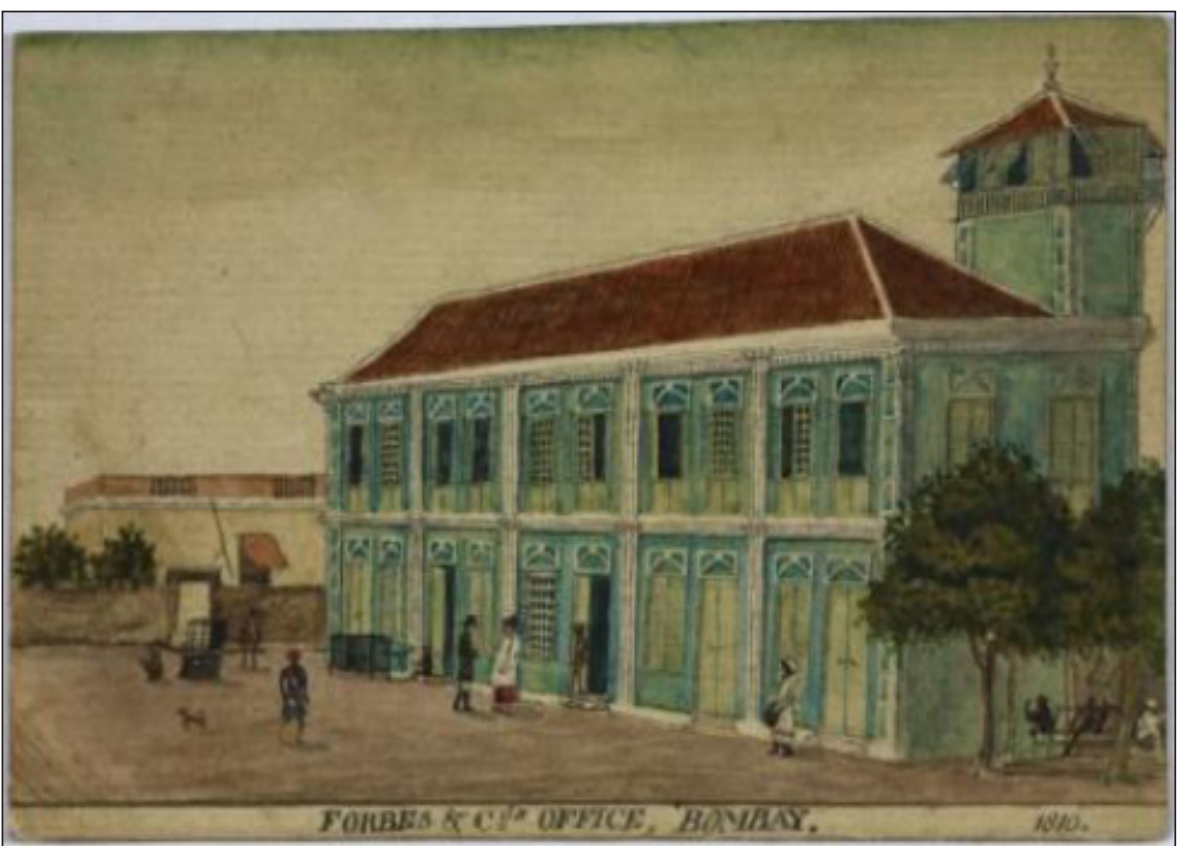

Figure 3. Forbes \& Company's office, Bombay. 1810; British Library, BL/WD 315 no.10 [http:// britishlibrary.typepad.co.uk/untoldlives/2013/01/forbes-and-companyone-of-the-oldest-businesses-in-the-world.html].

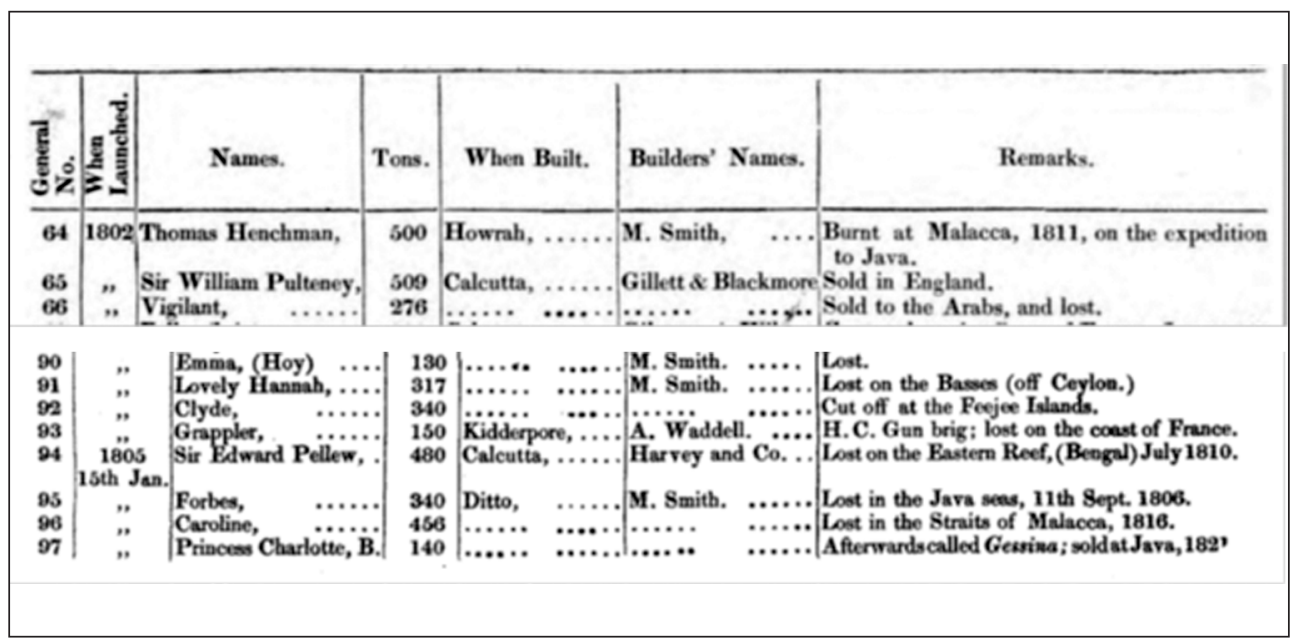

Figure 4. The Forbes' entry in Phipps' Collection of Papers Relative to Ship Building in India (Phipps 1840: 100-101).

If the Forbes' owners and captain had speculated to capitalize on chartering the vessel to her Bombay namesakes, their efforts apparently didn't bear fruit: Back in Calcutta in February 1806, she was fitted out for an "Eastward trading voyage", and, with a "cargo of opium, piece goods, and iron", left the Hooghly 
on 5 April 1806. Her voyage took her to Sulu, then destined for a brisk trade in British-Indian "war stores, opium, and textiles", ${ }^{5}$ the locally produced sea cucumber, mother of pearl, and birds' nests so coveted on the Chinese market, and the Spanish Dollars of South American mints that came to the Philippines with the yearly Manila Galleons. The Forbes' hoard of species is a true telltale of an English merchant-sailor's interest; for the datu of Sulu, on the other hand, the "arms, powder, and lead" supplied by British country traders were "essential to maintain their hegemony in the region" ${ }^{6}$ by, above all, providing the Sultanate's slaving and privateering fleets with their indispensable tools. Opium, then, was a major consumer article redistributed by Sulu rulers to their cohorts - and didn't it, as so aptly expressed in a Buginese hero's elegy of the early years of the twentieth century, have "a long tradition / as opener of the heart / to constant thoughts / concerning the goods of the villagers" 7 the Sulu raiders so regularly sought? The Forbes, anyway, stayed for only the five days between 22 and 27 May, ostensibly so to avoid raising too much of the Sulunese partiality for Western goods and vessels that, as was well-known in those days, could easily lay a lingering sailor's life and ship on the line. ${ }^{8}$

From Sulu the ship set a course to the southeast, and passing between Sulawesi and Halmahera made the Molucca Sea. Just as prudent seamanship commands - "from June to September, the E and S coasts of the [Obi] islands are inaccessible because of high seas" ${ }^{\prime \prime}$ - she then, most probably, rounded Halmahera through the strait between Bacan and Obira: A short note apparently taken out of the Forbes' log states that the vessel "on 20 June fell in with the American ship Eliza, off Pitt's Strait", ${ }^{10}$ a position she could not have touched at had she passed through the open waters north of Ceram (Seram). Her next recorded sojourn, between 30 June and 10 July, was "Warrow Bay", today's Waru Roads on the north-eastern end of the Island of Ceram that "afford safe anchorage at all seasons, in 29m, mud",11 we suppose that here her crew not only stocked on the "water and other refreshments [that] may be procured"12 in the hamlets lining the bay's southern shores, but also obtained the small cargo of nutmegs that was part of her homebound freight.

Our sources are silent about the Forbes' pursuits at the "several places on the Islands of Lombock and Bally" where she put in on her voyage back West. It took the ship nearly two months to reach Madura - and it seems that only here she was made aware of her unwarranted position of being an English vessel in an enemy's water:

James F. Warren (2007: 41).

Warren (2007: 41).

Roger Tol (1990: 189).

Compare for example, J.R. Logan (ed.) (1849-1851) and Warren (2007).

National Geospatial-Intelligence Agency (2004: 22).

10 This, and any unmarked quote following, is taken from an "Extract of a letter from Captain Sinclair, containing an account of the unfortunate loss of the Forbes of Calcutta", Supplement to the Bombay Courier, 03-01-1807.

11 National Geospatial-Intelligence Agency (2004: 50-51).

12 Horsburgh, James (1852: 744). 
On the 6th September about 20 miles to the Westward of the East end of the Island of Madura, fell in with the Dutch Frigate Phoenix from Batavia bound to Sourabaya, hoisted American Colours and passed within point blank shot of her; fired several shot at us in passing without doing any damage.

Finally, having reached seas frequented by Britain's opponents' shipping, the ship's company now commenced to hound the second goal of their voyage, privateering. Aptly prepared they were: Besides the vessel's guns were found stacks of grapeshot, an unmistakable preparation for close-quarter combat, intimating that looming in close on prey was the call of the hour. Not a day after the tryst with Phoenix, the Forbes thus "captured a Dutch brig from Batavia bound to Sourabaya with a cargo of Wine, Gin, Arrack, \&c.", well possibly the source of many of the bottles found on the wreck; a day later it was a further two Dutch vessels, sailing "in ballast from Batavia bound to some port in the East end of Java for Rice". We have not been left with a detailed account of the following affairs; though, would seem that the Forbes' second mate, a certain "Mr. Hitchings, with 16 men", 13 was given command of one of the latter prizes and permission to cruise on his own account.

Throughout the Java Sea, the ship's voyage westwards was remarkably fast: Since the encounter with the Phoenix on the sixth, the Forbes -including the taking of the brig with her spirituous cargo!- had made some 220 nautical miles in about 40 hours, so run at an average of at least six knots. It would now be roughly another 40 hours and a further 200 miles to Mampango reef - where she eventually foundered, "together with the Dutch brig taken on the seventh", thus loosing not only the ship, but also "the profits to a considerable amount" which the crew had amassed during the last six months.

Amazing as the Forbes' 1806 exploits might seem to a reader living in more settled times, they were but the bread and butter of a Country Trader. The extant newspapers and register volumes of those years recall many an adventurous scene: ample, apparently, were encounters with unwelcoming "natives"; spirited chase and capture of enemy's vessels (and, not rarely, a ship's successive recapture by her erstwhile owner); or foundering and loss of ships and fortunes. Just take, for our story, the "hostile treatment and subsequent melancholy death of Capt. Pavin of the Ruby, at Sooloo" in March 1800 (" poor Pavin, and the whole of the boat's crew, were cut to pieces - they [the Sulunese] made a present of Pavin's hat, and the boat, to Captain Porter"14 of the Apollo, calling at Jolo in June that year); or the Jonathan Duncan's passage through Pitt's Strait in December 1801, where she was

attacked by eight very large canoes in a most daring manner, who discharged a heavy flight of arrows at the ship, by which four men were dangerously wounded, two of whom died a few days later in a delirious state, owing to the arrows being poisoned (AAR 1802 1803: 10-1). 
A hearty "discharge of a heavy fire of musquetry" could dispel those more than 300 "men of a very savage appearance"; yet, the darings of a, say, French privateer, were a much different affair:

At half-past three p.m. we saw a ship on our lee quarter, in chase of us; at six o'clock the chase gained fast on us [...]; by eleven o' clock she was nearly alongside. We got the Armenia under a reduced sail, and all ready for engaging, hailed the stranger, but received no answer; she then hoisted French colours, and fired a shot into us, which was returned by a broadside of the Armenia. Every exertion was used to prevent the enemy boarding, which, from his manoeuvres, appeared to be his intention; we continued the action for about 40 minutes, when, finding that all resistance was fruitless, we were obliged to strike to the Clarisse, Captain Le Meme.

Our killed and wounded were, Mr. Baddeley, first officer, slightly wounded; Mr. Falconar, third officer, killed; the captain's steward and an European seacunney, dangerously wounded; two Portugueze seacunnies wounded (one since dead); [...] our sails and shrouds were very much cut up from their line of fire, which was about six feet above the deck. The Clarisse lost three men, which they say were in a boat which filled alongside; but, from the quantity of blood on her deck, we have reason to distrust their account (AAR 1801 1802: 23).

Most dreaded, however, was loss of ship and life in uncharted seas (and such were many of the waters negotiated by country traders), vividly portrayed with the foundering of Cato and Porpoise in Torres Straits, December 1803:

The Porpoise was scarcely a the ship's length from us to leeward, setting with her head towards us, and her broadside upon the reef; her fore-mast gone, and the sea braking over her [...] and when the day was broke, we had the mortification to perceive that the Cato had shared the fate of the Porpoise; the bow and bowsprit of the latter only, at intervals, appeared through the surf; the former lay with the bottom exposed to the sea, which broke with tremendous fury over her; not a mast standing. [...The one surviving ship's crew now] perceived that we had cleared the reef, but our congratulations were mixed with the utmost painful reflections on the sufferings of the crew[s] wrecked[, whom they] could not approach without certain destruction (AAR 1804 1806: 80ff).

Such dangers were, nonetheless, well outshone by the fortunes a successful voyage could make for the owner and captain of a country ship. Tapping into the fabulous riches of the European East India Companies, "country trade" meant commerce in all but the companies' monopoly goods, on all but the sea-lanes leading to Europe which, just as said commodities, had exclusively been chartered to the state-backed cartels. However, the mercantile dictates instituted by the various companies active in Asian waters were not necessarily of a uniform nature, thus furnishing interlopers under discrete flags with sufficient leeway to pursue their "ever a profitable business"; $;$ in addition, the private traders' deference for even their very own nation's monopolies 
left, more often than not, much to be deserved. Add to this the persistent venality of the East India companies' personnel, and the "sink of corruption and iniquity"16 that were the fifteen or so particular trading houses in Calcutta of the early 1800s becomes but a paragon for any of the ports and stations the various European powers had established throughout Asia since the sixteenth century.

The later seventeenth century had seen the heydays of the two main players of such commerce, the Dutch Vereenigde Oost-Indische Compagnie (VOC) and her counterpart, the English East India Company (EIC); the next hundred years, however, witnessed the protracted yet persistent decline of their fortunes. By the 1770s, both the Dutch and the English companies were technically bankrupt - but while the EIC was bailed out by parliament and the Regulating Act of 1773, the VOC tried her luck with short-term loans. The soaring defeat of the Netherlands in the Fourth Anglo-Dutch War of 1780-1784, the ensuing loss of the VOC's last footholds on the Indian subcontinent and the first concessions for a free British trade in the Malay Archipelago stipulated in the Treaty of Paris 1784, turned the pending amortization of the company's temporary credits into a hopeless affair; now, conversion into state-backed obligations appeared the only resort. Yet worse was still to come: By 1795 allied to Albion's enemy of choice, post-revolutionary France, the Lowlanders' trade came under constant harassment by the British Navy, virtually severing communications and commerce between the Dutch East Indies and Patria; in the East, vastly superior English fleets in 1796 took the VOC's late crowns, Ceylon and the Moluccas, still the major marts for cinnamon, cloves and nutmeg, the "fine spices" that firstly had lured the Western Powers into Asian waters. The Moluccas would be returned to the Dutch only with the shortlived peace of Amiens in 1802; Ceylon, though, was positively lost, while the ailing VOC, nationalized in 1796, already in 1798 had been declared bankrupt. Not that the EIC made better: By the early years of the nineteenth century her deficits "were running around $£ 2$ million a year"; under the 1797-1805 governorship of Richard Wellesley alone the company's debts rose from $£ 17$ million to a staggering $£ 31$ million, "around $£ 1.8$ billion"17 in today's money.

The ebbing fortunes of the two great companies opened a plethora of new opportunities for private merchant-sailors based in Calcutta, Madras and Bombay. Throughout the last decades of the eighteenth century the intra-Asian country trade hence advanced from a mere feeder network to an economic factor in its own right: in the 1780s alone, the number of clearances of independent vessels at the port of Calcutta rose from around 120 sail, carrying roughly 45,000 tons, to nearly 600 , representing a burthen of around 175,000 tons, "by which it appears that the country trade [...] had multiplied near four fold" (Phipps 1840: iv). The French Revolutionary Wars, raging since 1792, yet took an increasing toll of both privately owned and EIC ships,

16 Warren (2007: 38).

17 William Dalrymple (2004: 289). 
causing "a declension of nearly one half of the country trade"18 - and finally compelled the Honourable Company, in urgent need to replace the shipping space fallen to Britain's enemies, by the early 1800s to charter non-company vessels to carry Indian cargoes to China and even back to England.

Given the dearth in bullion that since its very beginnings had plagued Europe's eastern commerce, ${ }^{19}$ it for the western companies proved much more expedient to barter various Asian products obtainable in areas they controlled for the spices, tea, silk, and Chinese porcelain that formed the backbone of their business. In the China run, Indian cotton and, as we shall see in a moment, opium were the commodities of choice; particularly Bombay merchants greatly profited from such trade. ${ }^{20}$ For many a country trader based in Calcutta it though was the "Eastern Archipelago [that ...] furnished the means of an extensive commerce":

The demand for the produce of those Islands is unfailing, and that produce is only limited by the extent of the population. By means of the variety of its tribes, their intermixture and connexion with each other, and the accessible nature of the coasts, washed by the smoothest seas in the world; while large and navigable rivers open communication with the interior, the stimulus of this commerce is propagated in successive waves through the whole; and the inexhaustible resources of the country are drawn forth in a manner, and to an extent, that could not otherwise have been obtained (Phipps 1836: 318).

Here, raw cotton was not a promising medium of exchange: In great demand all over the islands were the gaily coloured "piece goods" of Gujarati and Bengal cloth the Forbes had carried on her outbound voyage. Of much better usance still were arms and drugs; today the ambit of crime syndicates, such merchandise was then, at worst, a semi-legal addition to an otherwise perfectly lawful trade. Many a country trader did not refrain from supplying even potential foes with an ordinance that might well be turned back onto its vendor - thus would much of the guns and powder that featured so prominently in the British trade with the Sultanate of Sulu eventually equip the Iranun's vessels of war and plunder, the most feared of all "Malay" raiders. Nonetheless, as an eyewitness of such a transaction observed, there were worthier goals than considerations of a moralist or strategic nature:

I saw the Sultan [of Mamuju in Sulawesi] purchase ten barrels of gunpowder [...], at 45 reals per barrel of half a picul; this was American powder. The usual price

18 Phipps (1840: iv).

19 To finance her Indian trade of the first centuries CE already "Rome, indeed, had to export so much gold in payment for Asian wares that Tiberius (14-37 CE) tried to restrain his subjects from wearing silk, and Vespasian (69-79 CE) tried to halt outflow of bullion" (Simkin, C.G.F. 1968. The traditional trade of Asia. London: Oxford Uni. Press, p. 23). Compare Miller, Innes J. (1998 [1969] The spice trade of the Roman Empire: 29 B.C. to A.D. 641. Oxford: Clarendon Press, Chapter 13).

20 Compare Anne Bulley (2000. The Bombay Country Ships 1790-1833. Richmond, Surrey: Curzon, Chapter 7). 
is from 80 to 90 reals per picul; muskets 15 reals each; [ ... while] the Americans sell their gunpowder at the rate of 22 and 24 dollars per picul, and their muskets, 7 dollars each. [W] hen such prices are considered, it need not be wondered at that such an extensive trade should be carried on. [...] Indeed, most of these rajahs consider their gold as of no other service than inasmuch as it enables them to purchase opium for their own use, and arms, ammunition \&c. for the assistance of their Bugis friends, and the annoyance of their great enemies the Europeans (Dalton 1837: 77).

It would appear that the arms' habitual companion, Indian opium, may well have equalized the former's truculent potential. The ruler of Mamuju we just met

and his brothers smoke opium in great quantities; [...] they are continually stupid, and will not see a stranger until time be given them to recover a little. When a prow arrived from Macassar with a letter to the rajah which the anakoda insisted upon personally delivering, he had to wait two days, before he could obtain an answer, during which time the rajah and his brothers were recovering sufficiently, to be sensible of the contents of the letter, and make some reply (Dalton 1837: 77).

Indeed, loss of motivation and impetus, one of the deplorable effects of the drug, could well have impeded belligerent impulses - yet again, it was not tactical deliberations, but lucrative acumen that drove its commerce. Since the EIC's 1757 annexation of Bengal, the Hon'ble Company virtually controlled India's main centres of the production of opium, a monopoly she artfully employed as, first-of-all, substitute for the bullion otherwise needed to purchase the Chinese tea that back home was in insatiable demand: Company officials in Guangzhou would buy tea on credit, covenanted by bills drawn on the next Calcutta opium auction; the drugs, the import of which, not without hindsight, was strictly prohibited by the Celestial Government, would then be conveyed aboard country vessels to some offshore station and smuggled into the China by their local business partners. ${ }^{21}$ In the East Indies, though, private sale of opium meant "only" trespassing the monopoly of the Amfioendirectie; the Dutch, anyway, had to buy the drug from the EIC, a trade that since the Hollanders' coalition with France had come to a virtual standstill - a perfectly opened turf, thus, for any an adventurous commander of a country ship.

Frazer Sinclair, the Forbes' captain, by 1806 was an old hand in such a commerce. Reportedly born in Stromness, Orkney Islands, in $1774{ }^{22}$ he makes his, as we assume, first appearance in the British registers for her Indian possessions as the "Sinclair, unemployed mariner" found in the "Madras list of seafaring Europeans" in The East India Kalendar ... for the Year 1797; at about the same time we find his, presumably, brother Patrick as seaman in Calcutta's

21 A fair number of contemporary detail concerning this trade may be found in Phipps (1836: 208ff).

22 This and the following data on the Sinclair family is found in The Whitton and Ritch Genealogy from Scotland (http:/ / www.robertwhitton.eu/ person.php?id=14451\&pat=Sinclair\& fam $=1$, last accessed 04-09-2015). 
pilot service. We could not locate these two Sinclairs in the lists of passengers or officers of outbound company vessels for the years in question, and neither are they registered in the list of "Free Mariners [...] who have proceeded to India, under the License of the Court of Directors" ${ }^{23}$ of the Hon'ble Company between 1793 and 1811 - one thus would imagine that they, as many a later officer in the country trade, had arrived in Asia as humble sailors on board an EIC Indiaman, and jumped ship at a convenient and promising BritishIndian port.

The sources available to us reveal only glimpses of how young Frazer began his career on -to use Marlow's epithet for the Asiatic waters to be traversed by the barque Judea of Joseph Conrad's Youth- the Eastern Seas. The first official mention of an F. Sinclair employed in a naval occupation is the "chief officer of the ship Anna Maria", ${ }^{24}$ sailing from Madras to Calcutta under the command of a John Cumming in October 1800, and we imagine that some years afore he had commenced his career, on any given country trader, as seacunny or petty officer, many of whom, it seems, weren't named in the lists of captains and officers active in India we could address. One would fancy that his later leanings as captain of a country ship were wrought by the accounts and encounters of those years, amongst which could well have been the fate of the pepper-trader Montgomery, out of Calcutta under command of a certain Alexander Sinclair, a possible fellow native of Orkney if not Stromness. ${ }^{25}$ In 1799 escaping a French corsair off Sumatra only due to the "spirited and judicious conduct" 26 of Captain Cumming, then in command of the Active, early next year the vessel, rumoured to carry "gold dust to the amount of 3000 Dollars" (Figure 5), fell prey to the privateer Buonaparte, ${ }^{27}$ commanded by François Ripaud de Montaudevert, the Jacobin gentleman of panache who in 1799 had offered French help to the unlucky Tipu Sultan of Mysore. Ripaud, with his wont civility, landed captain and crew at Tapanuli, whence they made their way back to India on board a Madras-bound ship, ${ }^{28}$ the Montgomery, though, by her captors despatched to France, was off South Africa retaken by a vessel of the British Cape Squadron, and eventually offered for public sale. ${ }^{29}$

23 Parliamentary Papers, House of Commons and Command (East India Company) (1813: 151, 395ff).

$24 \quad$ New Oriental Register and East India Directory for 1802 (1802: 168).

25 http://www.cursiter.com/txt-exe-files/Sinclair.txt, last accessed 01-10-2015, mentions at least three possible $\mathrm{Al}(\mathrm{l})$ exander Sinclairs born in Stormness between ca. 1750 and 1780, and a good dozen others from other Orkney settlements.

26 Madras Gazette 20-03-1799, taken from "a letter dated from on board the Active, the 26th of February, 1799 [... T] o the commander of the Active the owners of [... the Montgomery] would appear to be indebted for their safety"; compare documents P.P. 083-5 O. C. 15 Apr. No. 7, P.P. 1086 O. C. 15 Apr. No. 10 or P.P. $1122-3$ O. C. 15 Apr. D at the National Archives of India.

27 India Gazette 09-06-1800, 14-07-1800.

28 India Gazette 27-05-1800.

29 While the loss of the Montgomery in due time found its reverberations in the British Isles' papers (see, for example, the Aberdeen Journal, 02-03-1801, E. Johnson's British Gazette and 


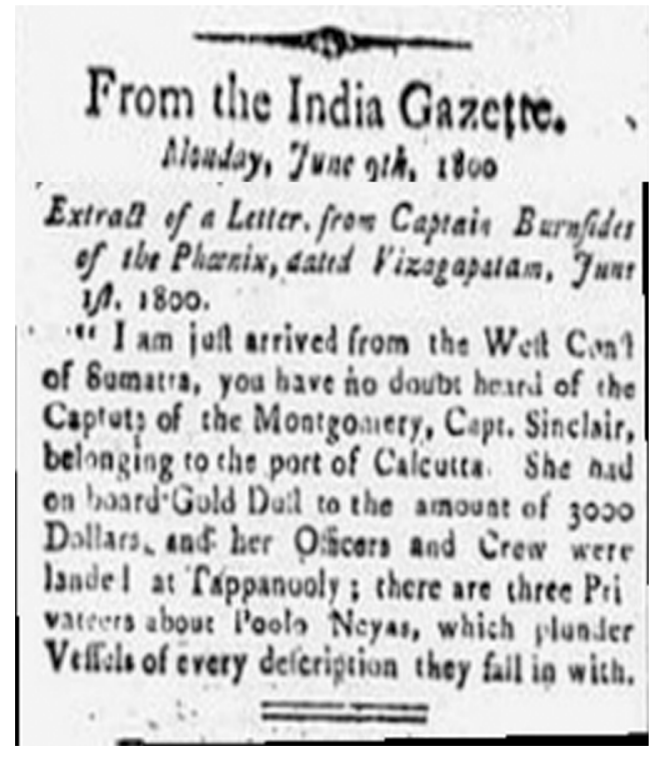

Figure 5. News of the loss of the Montgomery (Bombay Courier 11-07-1800).

In 1801 still captained by Cumming, 1802 found the Anna Maria under a new commander, William Garden or Gorden, trading to the Red Sea; ${ }^{30}$ Frazer Sinclair, however, by then was in charge of the Ruby, a Calcutta-built vessel of 250 tons owned by a certain George Jackson (Mathison and Mason 1802: 72). It appears that the ship from March 1801 to August 1802 was "taken up as transport" ${ }^{31}$ for Wellesley's and Baird's expedition to Egypt ${ }^{32}$ - except, though, for a note on having "received [her] provisions and sailed this morning [3103-1801]" 33 from Bombay to the Red Sea and a Ruby calling at Al-Qusayr in August $1801,{ }^{34}$ we could not discover any further news regarding the vessel's exploits in the sources available to us.

At some time after his return from Egypt, Frazer Sinclair was given a new command: Both the second edition of the East India Register and Directory for 1803 and the first for $1804^{35}$ note an F. Sinclair as captain to Alert, "a fine ship of 500 tons, [...] highly admired for [her] construction and the materials

Sunday Monitor 24-05-1801, or the Portsmouth Telegraph or Mottley's Naval and Military Journal 25-05-1801), first reports of the recapture of the ship off the Cape of Good Hope had arrived several months earlier in both India and England: see the Bombay Courier 11-10-1800, or the London Packet or New Lloyd's Evening Post 10/12-11-1800.

30 Bombay Courier 27-11-1802, quoting reports from Calcutta re her voyage from Corings, Mocha, and Aden; she eventually was lost in February 1803 off Ceylon (Bombay Courier 19-031803 and 25-03-1803).

31 AAR 1805 (1807: 145, 148, 152).

32 For that campaign and its sanitary repercussions of see Nair, Arpana (2009) "An Egyptian infection": War, Plague, and the quarantines of the English East India Company at Madras and Bombay, 1802", Hygeia Internationalis 8(1): 7-29.

33 Gurwood, John (1834: 87).

34 Bombay Courier 12-09-1801.

35 East India Register and Directory (1803, 1804: 96). 
of which [she] was built", ${ }^{36}$ and launched off the Calcutta yards of Messrs. Archer and Smith (who also were her "managing owners") in January of 1802. Under way "from Calcutta to China", she arrived "at Malacca, on the 28th November, [1802,] all well, and would take her departure thence on the 30th of the same month", ${ }^{37}$ of her return the Bombay Courier (30-05-1803) tells us that

[B]y private letters from Calcutta, we learn that the ship Alert had arrived in the River from Canton, whence she sailed on the 28th February. The intelligence brought by this vessel of the market for Cotton, is very unfavourable - the price was not only low, but daily falling.

In the meantime, the Ruby had on 1 February left Calcutta for England, chartered to the EIC as an "extra ship" for a voyage to Europe under the command of a certain John Hitchings. The voyage was not a happy one: Already at St. Helena the crew is quarrelsome; just ten days later, Hitchings at last "struck" his first officer, John Johnstone, for repeated drunkenness; a little on running into headwinds, the ship's seams started opening, and the pumps had to be kept running throughout the remainder of the trip, aggravating the decay of discipline aboard. While still under way off the English coast, the Ruby was boarded by the press-gang of a British man-of-war, giving Hitchings a convenient opportunity to get rid of the worst troublemakers - his reduced crew, though, now had to double their efforts on the pumps. The logbook of the passage ${ }^{38}$ leaves us, largely, with the impression that Hitchings failed to display the firmness expected from a superior officer on a long blue-water cruise; and this inaptitude perhaps was the reason that, seven months after her arrival in England, the Ruby set her course back to India under a Captain Blake (Supplement to the Bombay Courier 03-11-1804).

One wonders, whether the John Hitchings taking Ruby to Britain could not have been the same self as that J. Hitchings, the second officer of the Forbes who was to be given charge of one of her Dutch prizes, thus intimating an acquaintance of some standing with Frazer Sinclair. We, then, would certainly have to query the motives behind Sinclair's resolution to leave a secure berth as commander of a chartered vessel to his supposed companion (and, perhaps, erstwhile officer), at the very moment she was bound to sail to their fatherland. In any case, Sinclair apparently was not the man to hang his affairs into much of a limelight: as the reader will have noted, we know of most of his exploits only by second- or third-hand reports. Thus we also lose his trail after the Alert's return from China in the late spring of 1803 - on the ship's next recorded voyage, again to China and commencing in August that year (where she in September finds herself "becalmed in sight of Prince of Wales Island for six days, after leaving the port"), ${ }^{39}$ the vessel is in charge

36 Bombay Courier 20-02-1802, quoting the Calcutta Gazette of 28-01-1802.

37 Bombay Courier 29-01-1803.

38 See, Ruby: Journal, anon, 7 Jan 1803-17 Aug 1803, call-no. IOR/L/MAR/B/379 at the British Library.

39 Bombay Courier 10-12-1803, "based on a report from Prince of Wales Island". 
of a Captain Plum. Frazer Sinclair -with, at least in 1806, John Hitchings as his second officer- makes the next appearance we know of as captain of the Forbes on her way to Bombay in 1805, a calling that, as related above, ended, on September 11 of the following year, on Mampango reef.

A high-sea ship's boats are not the smallish affairs used to scull about on a Sunday afternoon's lake. Country vessels had to charge and discharge much of their cargoes in ports and anchorages without jetties, where their tenders would have to be most instrumental - hence, such boats were roomy enough for dozens of travellers, and, besides their sweeps, regularly carried a strikeable mast and sails. In the hands of capable mariners, these small vessels could perform surprising feats: the accomplishment probably best known is Captain Bligh's open-boat voyage, covering the amazing 3,500 nautical miles between the position of Polynesian Tofua, where the mutineers had left the loyal members of the HMS Bounty's crew to their fate, to Kupang in the Dutch East Indies.

The Forbes carried three tenders, onto which Sinclair divided the shipwrecked, himself, "Mr. Robert Sharp, 4th mate, and 11 of the crew in the pinnace [...]; the longboat with Mr. Hammond and Mr. Domain, 1st and 3d officers and 27 of the crew"; 40 and the remaining 36 sailors, probably under command of the serang or a seacunny, in the second longboat. The fate of the " 5 Javanese taken from the prize brig", irretrievably foundered just the same, remains unresolved: In the Prince of Wales Island Gazette it is claimed that they were divided into the boats; the "letter from Captain Sinclair" quoted in the Bombay Courier states that "the boats [were filled] with the whole of the ships company except 4 or 5 Javanese who refused to leave the wreck". After eight days of "the greatest distress from want of water and provisions under a scorching sun, without an awning or anything to cover them", the shipwrecked somewhere in the southern entrances to the straits of today's Singapore ran into the General Baird, last out of Calcutta under Captain Harford, "who with his wonted liberality supplied them with everything requisite for their further progress to Malacca".

The pinnace made Malacca on 22 September, three days after their falling in with the General Baird; the longboat under Hammond and Domain arrived on 25 September; by the time the news of the loss of the Forbes was to be printed, "the other boat ha[d] not yet made her appearance". The disheartened sailors seemingly contemplated about ways to recover their losses: The PWIG reports that:

the Penang Packet, Capt. Mathews, has been chartered and despatched by Mr. Douglas [the unlucky partner in a trading house operating in the commerce "between Penang, North Sumatra and Bengal" $]^{41}$ to the reef of rocks, where the Forbes and her Prize were unfortunately lost, for the purpose of endeavouring to recover some part of the property and treasure on account of the underwriters.

40 PWIG 11-10-1806. For the sources of further quotations related to the shipwreck and its direct aftermath used in this section compare footnote 2 above.

41 Nordin Hussin (2007: 79). 
We, however, do not know what became of these designs - the Penang Packet clears into the port of that name on 7 October, and again on 21 October, but carries no further news. Our next intelligence of the crew's whereabouts is the entry for 15 October in the logbook of HMS Harrier, under patrol duty in the Straits of Malacca, noting that, while anchored in the roads of Malacca, the vessel "receiv'd three men formerly belonging to the Country Ship Forbes Letter of Marque". ${ }^{42}$ It remains unanswered whether these men had decided that the strict discipline aboard a man-o'-war was preferable to the sufferings just endured, or merely intended to hitch a ride to Penang, where the Harrier was headed.

The stranded mariners' desperate circumstances took an unexpected turn on 22 October. "A stout Dutch snow, laden with a cargo to the value of 14 or 15,000 dollars," made the port of Penang, and was taken charge of by "a boat of one of H.M. ships [...] immediately on her anchoring" ; 43 inspection revealed the vessel to be under command of J. Hitchings, who, a short time after having been despatched with one of the Dutch brigs the Forbes had taken on 8 September, had fallen in with said snow, and judiciously placed the prisoners of both his first and the second prize on the former, smaller vessel, "allow[ing] them to make the best of their way to Java." We could not locate the respective entry in the surviving logbooks of the navy vessels at that time at Prince of Wales Island, and hence assume that Hitchings was apprehended by HMS's Greyhound or Lion, "the appointed convoy for the China fleet" 44 assembling at Penang, or HMS Blenheim, there stationed, all of which were, supposedly with their logs on board, lost at sea in the following couple of years. The Dutch prize, in the sources variously named Sinsore or Singsoy, was after some deliberations "given up on Thursday [23 October] to the Captors by His Excellency the Commander in Chief", Admiral Troubridge, flying his flag on HMS Blenheim. The snow and her cargo were promptly and publicly auctioned on Saturday, 1 November (Figure 6). We don't know how much the ship was worth - the above estimate for her cargo nonetheless amounts to roughly US\$180,000.- in today's silver prices. ${ }^{45}$ While this sum may not have been sufficient to compensate for the loss of a not yet two-year old ship of 300 tons, it probably would have helped refunding some of the outlays the underwriters had invested in the Forbes' voyage.

42 National Maritime Museum, Greenwich, ADM/LH/54.

43 PWIG 25-10-1806.

44 PWIG 15-11-1806.

45 Calculation based on +/- 25gr silver per Spanish Dollar; for silver exchange rate see http:/ / www.24hgold.com/ english/gold_silver_prices_charts.aspx?money=USD, last accessed 05-10-2015. 


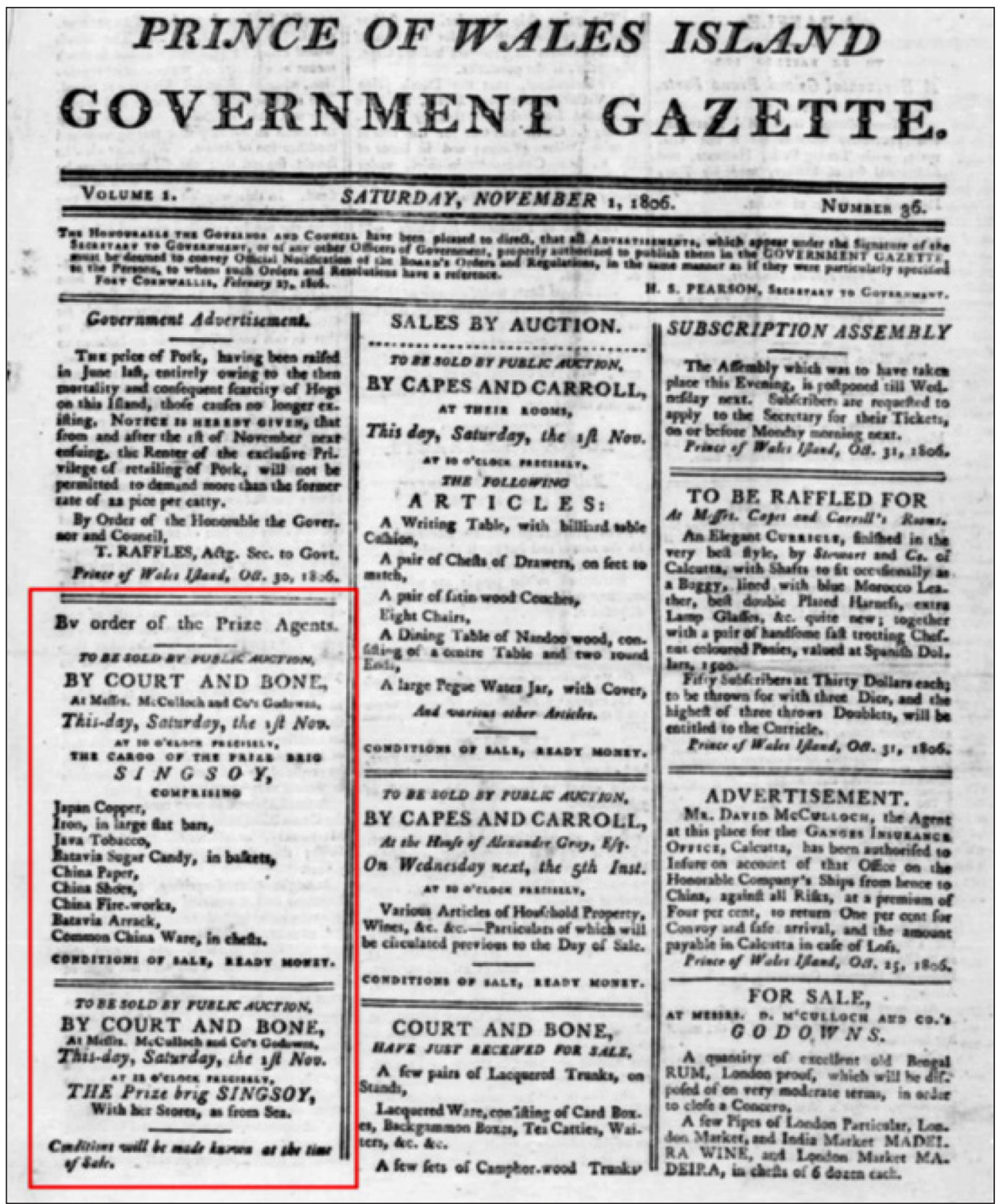

Figure 6. Advertisement for the sale of the prize Singsoy (PWIG 01-11-1806).

We cannot ascertain, how and when the late Forbes' company made their way to Calcutta - at least Sinclair, however, was back right in time to purchase the Farquhar, "burthen about 120 Tons, coppered; well known as a prime Sailer, and admirably adapted for a Run to the Eastward, with Opium, from the approaching Sales", publicly auctioned by Tulloh and Company on 4 December $1806 .{ }^{46}$ The auction thus took place a short fortnight before 18 December arrival in Calcutta of the Bengal convoy, "from Prince of Wales 
Island, whence they sailed on the 14th ultimo", ${ }^{47}$ implying that Frazer Sinclair had made his way to the Hooghly by some other, faster conveyance. The PWIG mentions only one ship leaving Penang for Calcutta before the departure of the convoy, the Jessy under Captain Kemp who cleared the island's roads on 5 November, but does not inform us of the vessel's eventual passengers.

By 1 January 1807, the Farquhar was registered to Frazer Sinclair as both managing owner and commander in the current "List of Shipping belonging to the Port of Calcutta"; 48 and already early in February the ship passed Malacca - now though, suspiciously, without (as far as we know) a note of her departure from the Hooghly, and without calling at Prince of Wales Island, then the main British station in the Straits. The local news does not inform us of purpose and destination of her voyage; yet, in an August edition of the Madras papers,

by the Kelvin Grove, arrived here from the Eastward, last from Penang the 16th ultimo, we learn, that the Farquhar, Captain F. Sinclair, who sailed from hence on a trading voyage to the Eastward, and equipped as a Letter of Marque, has captured several Dutch vessels; one of which arrived at Penang, prior to the departure of Captain Dundas from thence; and two others had reached Malacca. A large Spanish Vessel also struck to the Farquhar; but Captain Sinclair thought it most prudent to relinquish this prize, she being crowded with Europeans, and his own vessel but thinly manned with Lascars, many of his crew having been put on board the other vessels captured by him (Bombay Courier 12-09-1807).

The PWIG this time sports no advertisements for the sale of Sinclair's prizes, and the short reports on the ship's homeward voyage do not contain more than the mere dates of her journey: At Prince of Wales Island we are notified that "on Monday last [20 July] anchored in the harbour, the ship Farquhar, Capt. Sinclair, from Malacca, left the 18th instant" , and, "on Sunday next will sail for Calcutta, the ship Farquhar";49 in Calcutta, "on Friday [21 August] accounts were received of the arrival in the river [Hooghly] of the ship Farquhar, Captain Sinclair, from Penang the 20th ult. [...] Passengers per Farquhar: Capt. Mackay, and Mr. Arratoon" ${ }^{50}$ One is inescapably left with the impression that the exploits of this seven-months cruize were not necessarily intended for public consumption, and certainly wonders how Sinclair could have arranged for a valid Letter of Marque in the short two months between his purchasing the vessel and leaving Calcutta - proper privateering, after all, was subject to the authenticity of such a license, without which a prize court would not legalize condemnation of any given ship and cargo taken, thus encumbering proposals for a public sale.

However, any such inconveniencies were not the tune of the year to come. In May 1808, Captain Scott of the Hon'ble Company's vessel Tweed reports 
of "a vessel of suspicious appearance [...] off Pulo Aur; but which from the information he afterwards obtained at Malacca, he found to be the Farquhar privateer, from Calcutta, commanded by Capt. Sinclair"; 51 by October, news arrive in Calcutta that "Captain Sinclair, Commander of the Farquhar (Letter of Marque) had captured two Dutch prizes of considerable value, and that one of them had reached Penang". ${ }^{52}$ This would have been the Farewell, "taken by the Farquhar [...] on the coast of Java" and conveyed by her prizemaster, a Mr. Robert Sharpe; the 3 September 1808 edition of the PWIG adds that Sinclair and crew are "said to have taken, during [their] present cruize, eight prizes: four of which had been sent off, with orders to remain at this island, until the arrival" of the privateers' vessel. A fortnight later we are informed that "Captain Sinclair, of the Private Ship of War Farquhar, had arrived at Malacca, from the Eastward, with two prize brigs [... and], with her prizes, may be expected here, very shortly". A third "brig prize [...] got on shore at Tanjung Bolus", but, afforded immediate assistance by the Farquhar, was afloat again in due time; and by 19 September Sinclair, with "the Dutch brigs Fortune, Helder, and Fredda, and an Arab ship, which came from Semarang, laden with sugar and tobacco" anchored in the roads of Penang. The best part of the unfolding story is, perhaps, the lot of the Copenhagen ship Susannah,

taken by the Farquhar, on the coast of Java, on the 15th of March last, [which] has not been heard of since; [...] there were on board her, the prize-master, Mr. Bethumy Walker, the Danish commander, his clerk, carpenter, and carpenter's mate, a few slaves who were promised their liberty; and thirty-three people from the Farquhar. Capt. Sinclair having since taken, for the second time, the first and second officer of the ship Susannah, was informed by them, that she had on board, when taken, two chests of gold, a quantity of quicksilver, and camphor-wood; amounting, altogether, it is supposed, to a very considerable sum; a circumstance of which, at the time of the capture, Capt. Sinclair was entirely ignorant (PWIG 24-09-1808).

The sources available to us cannot unravel the Susannah's and her prize crew's further fate; the PWIG though, in quick succession throughout the coming weeks, advertised the Farquhar's prizes and her cargo for auction (Figure 7). Of considerable interest to the seafaring public was "that Capital fast sailing brig the Fortune, burthen about 180 Tons; [...] a remarkably fine vessel, built at Java, of Teak; well calculated for an Eastern Trader, and mounts Eight long four-pounders" (PWIG 10-10-1808). The Farquhar and her crew left Penang by 17 October, before the last of her spoils had been taken to market - nonetheless, the ship, as "we learn with concern" from the Calcutta Gazette of 16 November 1808, "in her passage up the river [Hooghly], ha[d] been stranded and wrecked, a little below Culpee"; fortunately, this time "the Treasure and Tin, which formed part of her cargo, will yet be recovered".

51 Calcutta Gazette 04-05-1808.

52 "Nautical Chronicle and Naval Report [from] Calcutta, October 3d 1808", in Bombay Courier 29-10-1808. 
With the Farquhar's foundering her affairs were all but over: The owner of the Arab ship filed a case against the detention of his vessel and cargo, forwarded to the Calcutta prize court, from where, by October next year, orders were received at Penang "to restore the Arab Ship named Shilanoon, together with her Stores or Cargoes, or the proceeds of the Sales thereof, to Syad Abdulla Semanthaan, the former Naqueda of the ship" (PWIG 14-10-1809).

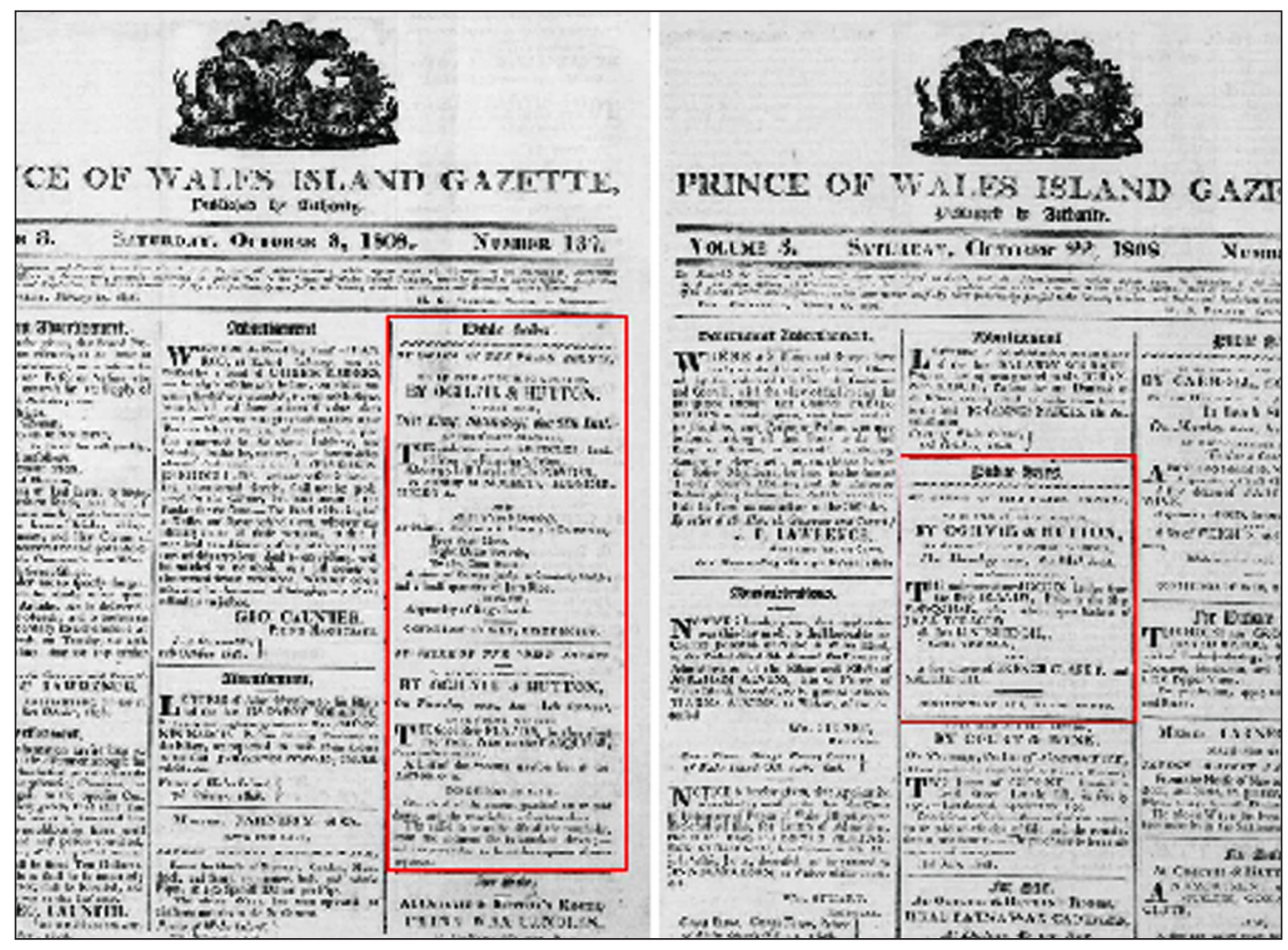

Figure 7. Advertisements for auctions of Farquhar's 1808 prizes (PWIG 8-10-1808 and 22-10-1808) .

Back in Calcutta Frazer Sinclair meanwhile had taken command of the Emma, "a very beautiful ship, constructed upon the model of a sloop of war, and said to be peculiarly adapted for offense and defence", launched on 25 November 1808, carrying 440 tons and named after Matthew Smith's, her builder's, daughter. We remain uninformed of Emma's concerns except for her arrival at Bombay on 14 November of the next year; 53 by March 1810 we yet find her, together with the country ship Troubridge, readied to take the newly appointed "staff and suite of his Excellence the Commander in chief" of Madras Presidency from Calcutta to their station. ${ }^{54}$ It would appear that at some time thence Emma was chartered by the Royal Navy as relief and transport for Rowley's hard-pressed squadron off Isle de France, where she

54 PWIG 14-05-1810, quoting the Calcutta Telegraph 13-03-1810. 
arrived, "armed on the emergency" 55 with the guns of the East-Indiaman Windham and in convoy with HMS Boadicea, in August 1810, only to note that they were "too late to afford the necessary succours" 56 for the British ships meanwhile lost in the disastrous Battle of Grand Port (Figure 8). Emma was given patrol duties "off Rodriguez to warn any passing British vessels of the danger from the French squadron" ${ }^{57}$ that had recently arrived to reinforce the defence of the French Indian Ocean Islands; later that year, she, together with HMS Hesper, surveyed the bay where the landing party destined to take Port Napoleon on 2 December 1810, was to be set ashore. "Intelligence from the Mauritius" printed in the PWIG of 11 March 1811, informs us that the last labour of "the armed ship Emma, Captain Sinclair" in the campaign was to be

fitted up for the reception of General De Caen [the French defender of Isle de France], and his suite [...] to set sail on the 16th Dec.[] General Abercrombie having positively refused to allow De Caen to remain longer on the island.

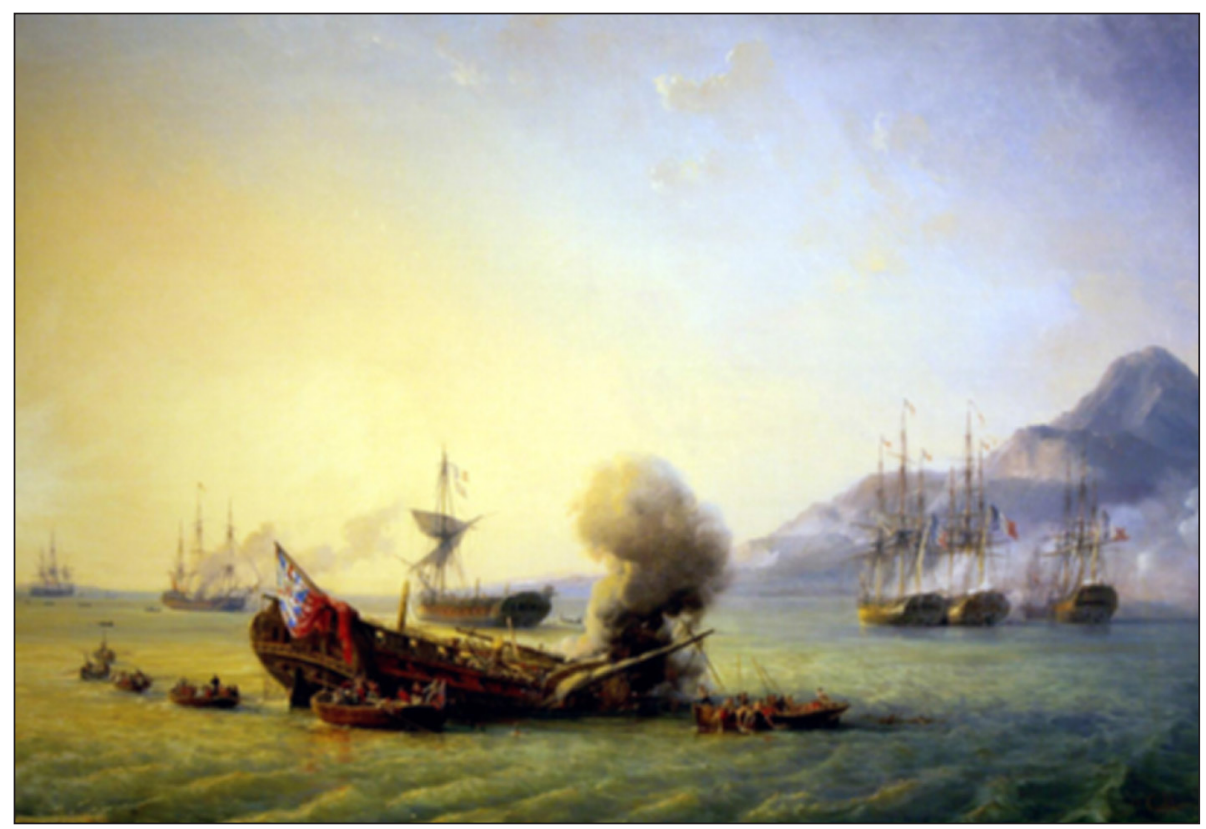

Figure 8. Le Combat du Grand Port, 23 août 1810 ('Battle of Grand Port, 23 August $\left.1810^{\prime}\right)$, Pierre Julien Gilbert, 1842, Musée national de la marine. From (far) left to right: HMS Iphigenia, surrendered to Admiral Hamelin on 28 August; HMS Magicienne being scuttled by fire; (foreground) HMS Sirius being scuttled by fire; (background) HMS Nereide surrenders [24 August]; (right) Duperré's squadron, the French frigates Bellone, Minerve, and Victor [https:/ / upload.wikimedia.org/Wikipedia/commons/ c/c6/Grand_Port_mg6971.jpg].

$55 \quad A A R$ XI-1810 (1812: 54).

56 Bombay Courier 15-12-1810, quoting "Calcutta Intelligence" from 23-11-1810.

57 http://cannonade.net/mauritius.php, last accessed 14-09-2015; for this and the above, compare Letters of Captain Rowley copied from an English Paper of the 13 February in Supplement to the Bombay Courier 26-06-1811. For a "romanticized" account of the overall campaign see Patrick O'Brian's The Mauritius Command, first published 1977 by Colins, UK. 
For the Emma, the conquest of Mauritius was not an unrewarding episode: Even a London Gazette Extraordinary of 13 February 1811, ${ }^{58}$ knows to report that "the Admiral [by then, Albemarle Bertie] warmly praise[d] the conduct" of her crew, and still in 1828 the ship's company was called to claim their shares in the "fourth and final distribution of the prize property" made at Isle de France (London Gazette 1828: 1376). De Caen eventually "embarked on board the Emma Transport with his family and suite on the 24th December", ${ }^{59}$ to be repatriated via the Cape of Good Hope, where she called in January 1811. Yet, as successful as ever she might have been throughout the campaign, by August of that year (thus we assume, shortly after her return from Europe) the ship was sold to the Calcutta firm Fairlie, Ferguson and Co., and placed under the command of a certain A.G. Noayle (East India Register and Directory for 1811: 119).

We don't know whether Sinclair didn't find himself the man to, as was usual on a civilian ship turned man-o'-war, serve as mate under a navy officer (represented by, at least during the survey for the landing stage on Isle de France, a certain Lieutenant Street) ${ }_{1}^{60}$ or whether he still felt uneasy at the prospects of a voyage home; he, anyway, after the cessation of the campaign appears to have made his way to Madras on one or other of the India-bound troop transports. There, it would seem, he could not refuse hastened requests to contribute his knowledge of the Eastern Islands to the Madras division of the fleet readied in the early months of 1811 for an invasion of the island of Java - in any case, he under the tempestuous conditions ${ }^{61}$ of 18 April left port as one of the pilots of the expedition. The nature of his appointment was, apparently, not overly dependable: Still in January 1812 he "reasons and solicits payment of his allowances as Pilot to the Fleet on the late Expedition" with the "Government of Fort St. George" (National Archives of India 10-011812).

Somewhen in early 1812 Sinclair acquired his last command, the Lady Rollo. We find the vessel already in 1811 advertised as

built of teak, [...] launched at Calcutta in October last, burthen 120 Tons Carpenter's Measurement; her Rigging \& principal Sails are new, and of the best quality, she is well found in Stores, and may be sent to Sea at a very trifling expence, \&c is well calculated, for the Gulph, or Malay trade (Bombay Courier 22-06-1811).

By now, privateering in the Malay Archipelago is done with: After having taken Java in 1811, Minto and Raffles had spread authority and reforms throughout the islands, guaranteeing free and unmolested trade for any Dutch burgher, native nakhoda or British country trader alike. Hence, in 1812

\footnotetext{
58 As quoted in Nichols (1811: 171).

59 Bombay Courier 23-02-1811.

60 AAR 1810-1811 (1812, “History" p. 16).

61 William Thorn (1815: 2f).
} 
Sinclair conveyed cargoes of "Opium and Bee's wax"62 or timber along the coasts of Java; there would also be the occasional passenger, just as the "three Women belonging to H.M. 14th Regt." ${ }^{63}$ stationed at Semarang who aboard the Lady Rollo went to Batavia in October of that year. His goal, one assumes, would have been those "Eastward Trading Voyage[s]" between Calcutta and the Archipelago that he had pursued with Forbes or Farquhar, by now but for the privateering part. His exploits appear to have been rewarding enough: In 1813 Sinclair could semi-retire as supercargo, leaving the daily handling of the vessel to a certain Captain Pringle.

However, returning from the southern Moluccas and Timor, the Lady Rollo on 13 September that year

struck a shoal situated in lat. $7^{\circ} 45^{\prime} \mathrm{S}$ and about 40 miles S.E. by E. distant of Flores' Head, and after some hours, during which unsuccessful attempts were made to get her off, she bilged, and was totally lost, with the whole of her cargo. [...] the Commander, Supercargo (Mr. Sinclair,) Officers and Crew, in all 38 persons, saved themselves in the boats of the vessel, and made for Bima, where they arrived about the 20th ultimo. It appears that they were not received be the Rajah of that place with all the hospitality which their distress entitled them to claim. He refused to afford them any assistance, and they owed the means of quitting Bima to the friendly aid of a Chinese, who furnished them with a Prow, in which they arrived at the port of Bisuki in the night of the 12th instant (Java Government Gazette 30-10-1813).

We wonder if not this, now third, loss of vessel tore a string in Frazer Sinclair's perseverance. As the Calcutta Gazette of 24-01-1814 knows to report,

we have already had the mortification to announce the total loss of the ship, Lady Rollo of this port, on her return from a trading voyage to the Moluccas. One of the Seacunnies, who escaped from the wreck, and arrived in Calcutta about a fortnight ago on a vessel from Batavia, has at length been found and states on his examination, the following circumstances; viz.

"The Lady Rollo remained about a month at Amboyna, and then returned to Timor. At that port she remained about five or six days and then proceeded to Timor Koopayn, where she remained about five or six days and then left it. About the month of September last, about 6 o'clock A.M. and when we were about 2 or 3 days sail from the Island of Narrain Tokar, and out of the sight of land, the brig took the ground, and continued in that stated till about 12 o'clock, when she was got off; and in the course of an hour after she again took the ground, and after every exertion was used by endeavouring to tow her off with her boats and otherwise, Captain Sinclair on the following morning desired all hands on board to leave her; which being done, he set the wreck on fire, and burnt her up, with her cargo and all things on board, including clothes and all the stores, with the exception of the clothes we had on, a bag of rice and a keg of water, and some few common necessaries which we took with us." 
Yes, indeed,

Fortunes no doubt were quickly made in those days, and often equally quickly lost. In the latter misfortune if the skipper haply possessed a mercurial temperament, he would betake himself again to his congenial task; if not, he passed out of the arena and another took his place. Many a quiet village churchyard at home shelters the remains of some doughty mariner, who after a career out here in days of stress and strife, wended his ways to his native place, to enjoy his competence and end his days in peace (Coates 1911: 104).

Now in his early forties, Sinclair must have found the latter prospects promising enough to turn his thoughts back home - and we will see in a moment that his years of adventure and audacity in the East had furnished him with a fortune sufficient to "end his days in peace" in the lands of his birth. However, such longings would certainly have been augmented by his deteriorating health: When eventually boarding the Maister, under Captain William Wiseman homebound out of Calcutta on 25 October 1815, "he was at that time so very ill that he complained of living to reach England". ${ }^{4}$

We cannot ascertain how Frazer Sinclair arranged his way back home. There's a "Sinclair' leaving Batavia on a Ruby, Captain Hamilton, for the Cape of Good Hope and Calcutta on 14 December 1814, ${ }^{65}$ sufficiently in time to catch the Maisters, on which he was eventually berthed, at Bengal. He must have had a clear presentiment of his end a-loom: "Previous to his coming on board the said ship he informed [Captain Wiseman] the he had made his will in Calcutta", and it is conceivable that he had chosen a lengthy trip on the $R u b y$ to alleviate the respiratory ailments he was suffering from with the fresh air of the Indian Ocean. He carried a copy of his testament aboard, as, "when a person in that Country [of Bengal] makes a will it is usual for the Original Will (Figure 9) to be left in the East Indies for his Executors". Frazer Sinclair perished on the Maisters, just two weeks after her leaving the Hooghly, on 8 November 1815, "of a violent Asthma with which he was afflicted".

64 All unmarked quotes in the following are taken out of the official procedures surrounding the execution of Sinclair's will, found at http:/ / search.findmypast.com/results / world-records?firstname $=$ frazer\&lastname $=$ sinclair\&yearofdeath $=1816 \&$ yearofdeath_offset $=0$, last accessed 01-10-2015.

65 Java Government Gazette 17-12-1814. 


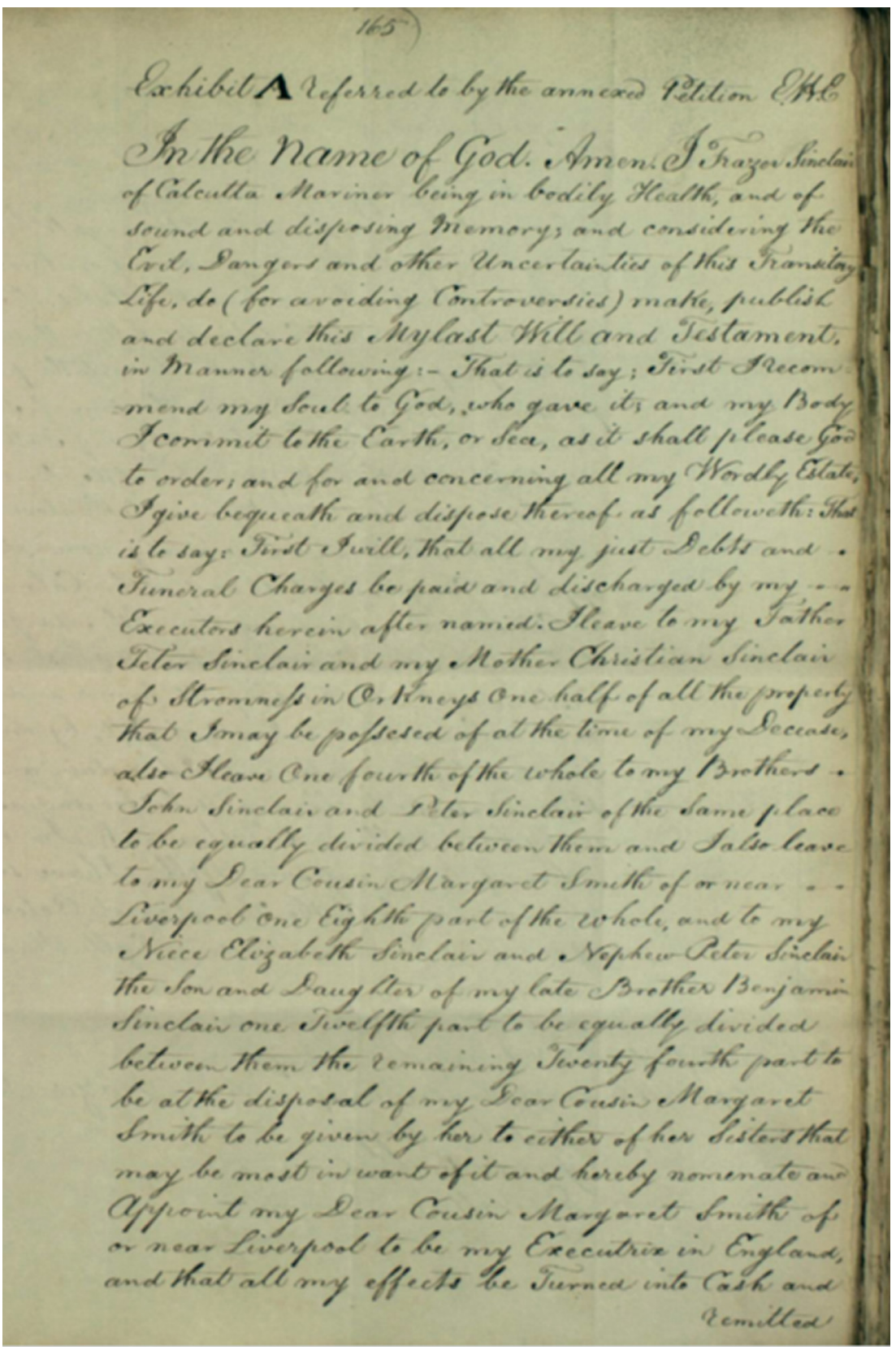

Fig. 9 First page of Frazer Sinlcair's Last Will [www.findmypast.co.uk].

He didn't die a poor man. Throughout the next couple of years George Mitchell, his appointed executor in Calcutta, transferred 69,511 Sicca Rupees, roughly $£ 365,000,-$ (or US\$550,000,-!) in today's money, to England (Figure 10). Frazer Sinclair had pledged to "my father Peter Sinclair and my mother Christian Sinclair of Stromness in Orkneys one half of all the property that I may be possessed of at the time of my decease", bestowed one fourth of the 
funds to his brothers John and Peter, "to be equally divided between them $[\ldots$,$] and to my niece Elizabeth Sinclair and nephew Peter Sinclair the son and$ daughter of my late brother Benjamin Sinclair one twelfth part". He further bequeathed "to the Poor of the Parish of Stromness in Orkney the sum of Sica Rupees four hundred to be distributed by my father or in case of his death by the Minister of the parish". Nonetheless, he chose to

nominate and appoint my Dear Cousin Margaret Smith of or near Liverpool to be my Executor in England and that all my Effects be Turned to Cash and remitted to her with a copy of this will for the purposes above mentioned to be addressed to the home of Mr. Arthur Smith Merchant Liverpool.

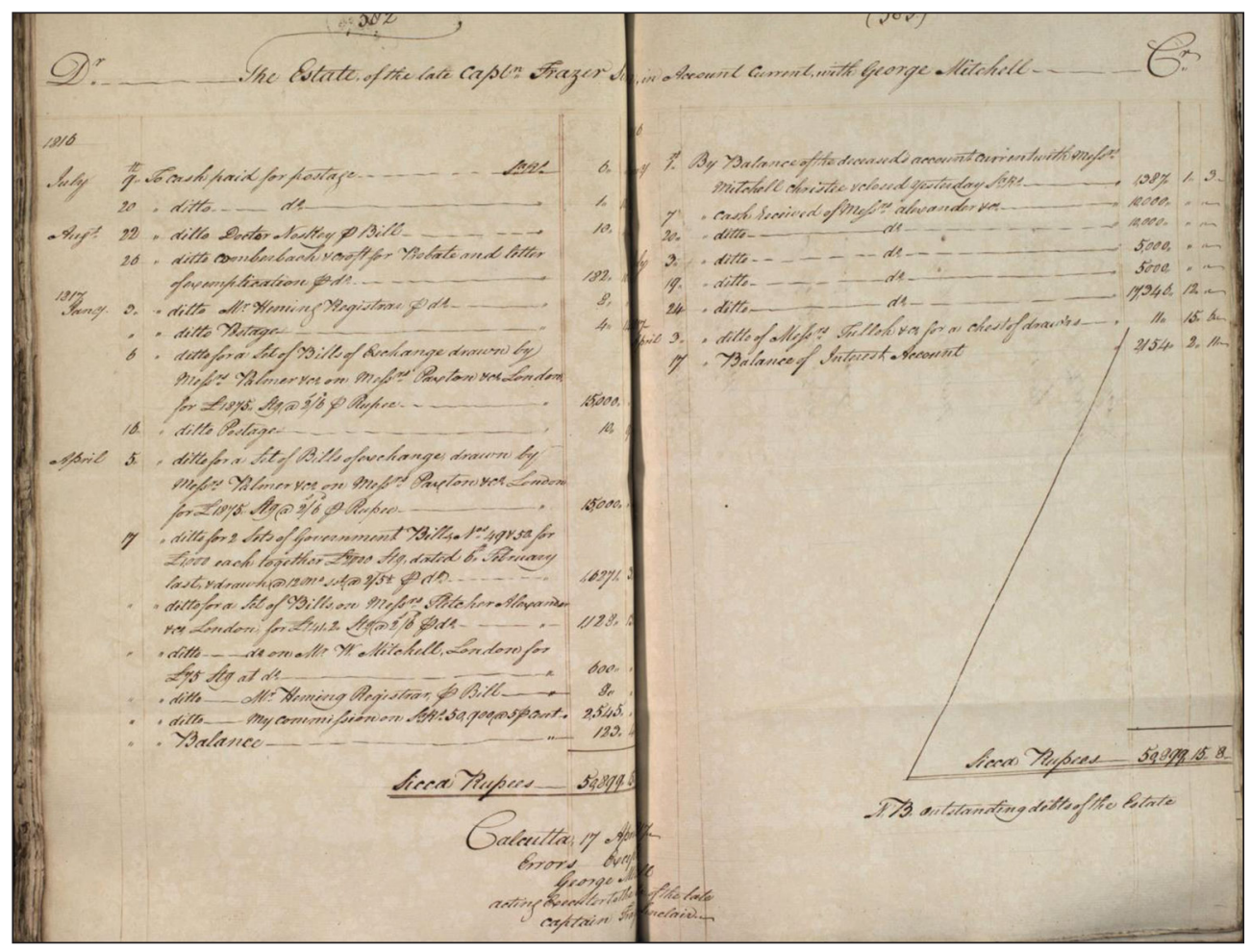

Figure 10. Summary of the sums transferred to England in course of the execution of Sinclair's Will [www.findmypast.co.uk].

He also entrusted his "seal and broach to the above named Margaret Smith"; and she, spinster still, made the journey to London to prove, on 12 June 1816, "before the judge by oath [...] the truth of this Affidavit". And while the news of Frazer Sinclair's unfortunate demise made their way back to India (Figure 11), she, nay, might have preferred him to have 
Escap'd with life, in tatters,

Behold me safe on shore,

Such trifles little matter,

I'll soon get togs galore:
For Poll swore when we parted

No chance her faith would jar,

And Poll's too tender-hearted,

To slight a shipwreck'd tar.

(Charles Dibdin, The Shipwreck'd Tar, 1803)

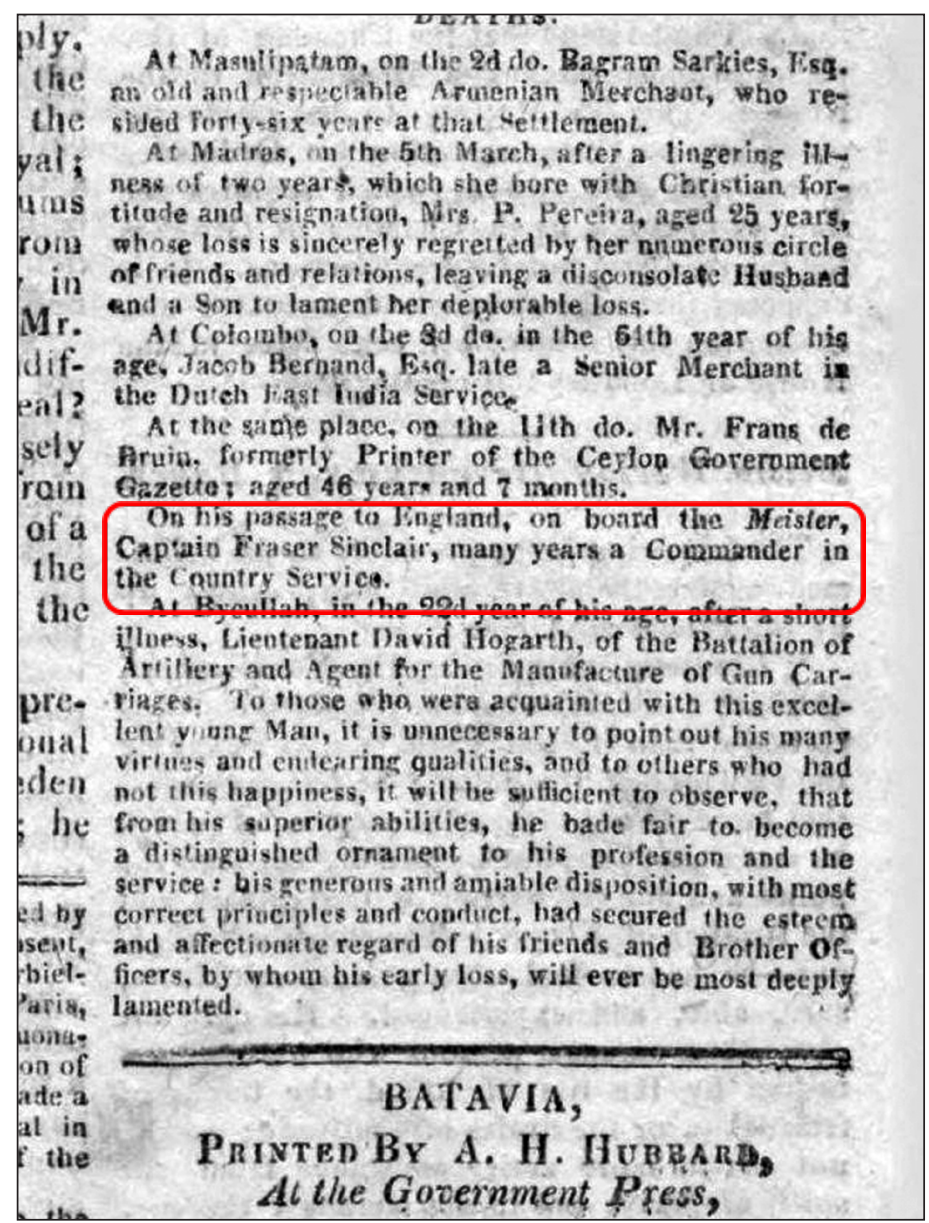

Figure 11. Obituary for Frazer Sinclair, Java Government Gazette 08-10-1816.

\section{REFERENCES}

\section{NEWSPAPERS/PERIODICALS}

Asiatic Annual Register. 1802. The Asiatic annual register, or, A View of the history of Hindustan, and of the politics, commerce and literature of Asia, for the year 1801. Edited by Lawrence Dundas Campbell. S.1: s.n.

Asiatic Annual Register. 1803. The Asiatic annual register, or, A View of the history of Hindustan, and of the politics, commerce and literature of Asia, for the year 1802. Edited by Lawrence Dundas Campbell. S.1: s.n. 
Asiatic Annual Register. 1806. The Asiatic annual register, or, A View of the history of Hindustan, and of the politics, commerce and literature of Asia, for the year 1804. Edited by Lawrence Dundas Campbell. S.l: s.n.

Asiatic Annual Register. 1807. The Asiatic annual register, or, A View of the history of Hindustan, and of the politics, commerce and literature of Asia, for the year 1805. Edited by Lawrence Dundas Campbell. S.l: s.n.

Asiatic Annual Register. 1811. The Asiatic annual register, or, A View of the history of Hindustan, and of the politics, commerce and literature of Asia, for the year 1808, Vol. X. Edited by E. Samuel. S.1: s.n.

Asiatic Annual Register. 1812. The Asiatic annual register, or, A View of the history of Hindustan, and of the politics, commerce and literature of Asia, for the year 1810-1811. Vol. XII. Edited by E. Samuel. S.l: s.n.

Bombay Courier 11-07-1800. British Library Newspapers. Bombay Courier 11-10-1800. British Library Newspapers. Bombay Courier 12-09-1801. British Library Newspapers. Bombay Courier 20-02-1802. British Library Newspapers. Bombay Courier 27-11-1802. British Library Newspapers. Bombay Courier 29-01-1803. British Library Newspapers. Bombay Courier 19-03-1803. British Library Newspapers. Bombay Courier 25-03-1803. British Library Newspapers. Bombay Courier 30-05-1803. British Library Newspapers. Bombay Courier 10-12-1803. British Library Newspapers. Bombay Courier 03-11-1804. British Library Newspapers. Bombay Courier 07-12-1806. British Library Newspapers. Bombay Courier 03-01-1807. British Library Newspapers. Bombay Courier 12-09-1807. British Library Newspapers. Bombay Courier 29-10-1808. British Library Newspapers. Bombay Courier 18-11-1809. British Library Newspapers. Bombay Courier 15-12-1810. British Library Newspapers. Bombay Courier 23-02-1811. British Library Newspapers. Bombay Courier 22-06-1811. British Library Newspapers.

Calcutta Annual Register. 1807. Calcutta Annual Register and Kalendar for the year 1807. Calcutta: Mirror Press.

Calcutta Gazette 28-01-1802

Calcutta Gazette 27-11-1806

Calcutta Gazette 18-12-1806

Calcutta Gazette 24-08-1807

Calcutta Gazette 04-05-1808.

Calcutta Gazette 16-11-1808.

Calcutta Gazette 24-01-1814.

East India Register and Directory for the year 1803. London: W. Allen. East India Register and Directory for the year 1804. London: W. Allen. East India Register and Directory for the year 1806. London: W. Allen. East India Register and Directory for the year 1811. London: W. Allen. India Gazette 27-05-1800. 
India Gazette 09-06-1800.

India Gazette 14-07-1800.

Java Government Gazette 12-09-1812.

Java Government Gazette 24-10-1812.

Java Government Gazette 30-10-1813.

Java Government Gazette 17-12-1814.

Java Government Gazette 08-10-1816.

Java Government Gazette 1828: 1376.

Java Government Gazette 26-03-1799.

Parliamentary Papers. 1813. Parliamentary Papers, House of Commons and Command

(East India Company), Vol. VIII, part 2. London: H.M. Stationary Office.

Prince of Wales Island Government Gazette 11-10-1806

Prince of Wales Island Government Gazette 01-11-1806

Prince of Wales Island Government Gazette 15-11-1806.

Prince of Wales Island Government Gazette 25-10-1806.

Prince of Wales Island Government Gazette 25-07-1807.

Prince of Wales Island Government Gazette 03-09-1808.

Prince of Wales Island Government Gazette 24-09-1808.

Prince of Wales Island Government Gazette 10-10-1808.

Prince of Wales Island Government Gazette 14-10-1809.

Prince of Wales Island Government Gazette 14-05-1810.

Prince of Wales Island Government Gazette 11-03-1811.

Supplement to the Bombay Courier 03-11-1804.

\section{BOOKS/ARTICLES}

Coates, William H. 1911. The old "Country Trade" of the East Indies. London: Imray.

William Dalrymple. 2004. White Mughals: Love and Betrayal in EighteenthCentury India. London: Penguin.

Dalton, John. 1837. “Mamoodjoo in Mandhar", in: Moor, James H. (ed.), Notices of the Indian Archipelago, and adjacent countries; Being a collection of papers relating to Borneo, Celebes, Bali, Java, Sumatra, Nias, the Philippine islands, Sulus, Siam, Cochin China, Malayan Peninsula, E c, pp. 75-78. Singapore. [Published in Singapore Chronicle, July 1831.]

Flinders, Matthew. 1814. A voyage to Terra Australis. Vol. 2. London: W. Bulmer.

Gurwood, John. 1834. The dispatches of Field Marshal the Duke of Wellington during his various campaigns in India, Denmark, Portugal, Spain, and from 1799 to 1818. Vol. 1. London: J. Murray

Horsburgh, James. 1852. The India Directory, or, Directions for Sailing, to and from the East Indies, Vol.II. London: Wm. H. Allen.

Logan, J.R. 1849-1951. "The Piracy and Slave Trade of the Indian Archipelago", Journal of the Indian Archipelago and Eastern Asia 3-5.

Mathison, John and Alexander W. Mason. 1802. A New Oriental Register and East India Directory for 1802. London: Black's and Parry. 
Miller, Innes J. 1969. The Spice Trade of the Roman Empire: 29 B.C. to A.D. 641. Oxford: Clarendon Press.

Nair, Arpana. 2009. “' An Egyptian infection'; War, Plague and the Quarantines of the English East India Company at Madras and Bombay, 1802", Hygiea Internationalis An Interdisciplinary Journal for the History of Public Health 8(1): 7-29.

National Archives of India. 1812. Ms. Public, O. C., 10 January 1812, No. 49.

National Geospatial-Intelligence Agency. 2004. Sailing Directions (Enroute): New Guinea. Ninth edition. Bethesda, Maryland: National GeospatialIntelligence Agency. [Pub. 164]

National Maritime Museum, Greenwich, ADM/LH/54.

Nichols, John. 1811. Gentleman's Magazine and Historical Chronicle Vol. 81/1. London: E Cave.

Nordin Hussin. 2007. Trade and Society in the Straits of Melaka. Singapore: NUS Press.

O'Brian, Patrick. 1977. The Mauritius Command. Glasgow: Colins.

Phipps, John. 1836. A Practical Treatise on the China and Eastern Trade. Calcutta: W. Thacker and

Phipps, John. 1840. A Collection of Papers Relative to Ship Building in India. Calcutta: Scott.

Thorn, William. 1815. Memoir of the conquest of Java; With the subsequent operations of the British forces, in the Oriental archipelago. To which is subjoined a statistical and historical sketch of Java with an account of its dependencies. London: T. Egerton.

Tol, Roger. 1990. Een Haan in Oorlog; Toloqna Arung Labuaja Een Twiintigste $\neg$ eeuws Buginees Helldendiicht van de Hand van i Mallaq Daeng Arung Majeneng. Dordrecht: Foris.

Warren, James F. 2007. The Sulu Zone, 1768-1898. Singapore: NUS Press. 